\title{
Ocena efektywności ekonomicznej procesu WAG na podstawie danych eksperymentalnych dla jednego z krajowych złóż ropy naftowej
}

\section{Evaluation of the economic efficiency of the WAG process based on experimental data for one of the domestic oil fields}

\author{
Mirosław Wojnicki, Jerzy Kuśnierczyk, Sławomir Szuflita, Marcin Warnecki \\ Instytut Nafty i Gazu - Państwowy Instytut Badawczy
}

\begin{abstract}
STRESZCZENIE: Problem związany z koniecznością zwiększenia stopnia sczerpania zasobów złoża dotyczy wielu dojrzałych, również krajowych, złóż ropy naftowej, w tym tych najważniejszych - zlokalizowanych w dolomicie głównym. Zapewnienie zadowalającego stopnia sczerpania jest możliwe jedynie dzięki zastosowaniu efektywnej metody wspomagania wydobycia ropy (ang. enhanced oil recovery, EOR). Naprzemienne zatłaczanie wody i gazu (ang. water alternating gas, WAG), jako jedna ze skuteczniejszych metod EOR, została przebadana w warunkach charakterystycznych dla krajowych złóż w formacjach węglanowych. Rezultaty prac eksperymentalnych, a także symulacyjnych prowadzonych w INiG - PIB wskazują na duży potencjał zastosowania metody WAG w warunkach krajowych. Niewątpliwą zaletą wykorzystania metody WAG jest możliwość utylizacji różnego rodzaju gazów, w tym gazów spalinowych/odpadowych lub gazów ziemnych o znikomej wartości energetycznej. Kwestia ta zasługuje na szczególną uwagę, gdyż jak wiadomo, ograniczenie emisji gazów odpowiedzialnych za globalne ocieplenie ma krytyczne znaczenie dla przyszłości naszej planety. Użycie w metodach EOR gazów, powiązane z ich bezpiecznym składowaniem w strukturach geologicznych, oraz wykorzystanie naturalnej energii złożowej to działania pozwalające na zmniejszenie śladu środowiskowego wydobywanej ropy. W niniejszym artykule, opierając się na wynikach prac eksperymentalnych, przeprowadzono uproszczoną analizę ekonomiczną wykorzystania w metodzie WAG czterech typów gazów: w postaci gazów kwaśnych (dwutlenek węgla i jego mieszanina z siarkowodorem) oraz gazów ziemnych (zaazotowanych i wysokozaazotowanych). Pozwoliło to na wytypowanie optymalnych pod względem ekonomicznym wariantów metody WAG. Przeprowadzone obliczenia wykazały, że pomimo znacząco niższej skuteczności zaazotowanych gazów ziemnych przy wspomaganiu wydobycia ropy (w kontekście uzyskiwanego współczynnika odropienia), ich zastosowanie może być uzasadnione pod względem ekonomicznym. Dobór optymalnego wariantu wspomagania wydobycia zależy w dużej mierze od przyjętych (aktualnych) kosztów pozyskania zatłaczanych mediów oraz ceny wydobywanego surowca na rynkach światowych.
\end{abstract}

Słowa kluczowe: wspomagane wydobycie ropy (EOR), zatłaczanie gazu, naprzemienne zatłaczanie wody i gazu (WAG), gazy zaazotowane.

ABSTRACT: The challenge related to the need for an increase of the recovery factor concerns numerous mature, also domestic oilfields, including the most important ones - located in Main Dolomite formation. Satisfactory recovery factor can be ensured only through applying an effective enhanced oil recovery method (EOR). Water Alternating Gas (WAG), as one of the most effective EOR methods, has been tested in conditions characteristic for domestic deposits in carbonate formations. The results of experimental and simulation works carried out at the Oil and Gas Institute (INiG - PIB) indicate significant potential for the application of the WAG method in domestic conditions. An unquestionable advantage of the WAG method is the opportunity to utilize various types of gases, including flue/waste gas or low-energy natural gas. This issue deserves special attention because, as we know, the reduction in the emissions of gases involved in global warming is critical for the future of our planet. Their utilization in EOR methods, coupled with their safe storage in geological structures, constitute measures that reduce the environmental footprint of produced oil. In the article, based on the of experimental results, a simplified economic analysis of the utilization of four gas types in the form of acidic gases (carbon dioxide and its mixture with hydrogen sulfide) and natural gases (high and very high nitrogen content) in the WAG method was carried out. That allowed to identify the most economically optimal variants of the WAG method. The results showed that despite significantly lower effectiveness of nitrogen-rich natural gases in enhancing oil recovery (in the context of recovery factor), their application might be justified in economic terms. The selection of the optimal variant for enhancing recovery is strongly influenced by the assumed (current) cost of acquiring the injected media, and of course by the current (and forecasted) crude oil price.

Key words: enhanced oil recovery (EOR), gas injection, water alternating gas (WAG), $\mathrm{CO}_{2}$, high-nitrogen natural gas.

Autor do korespondencji: M. Wojnicki, e-mail: miroslaw.wojnicki@inig.pl

Artykuł nadesłano do Redakcji: 27.11.2021 r. Zatwierdzono do druku: 08.02.2021 r. 


\section{Wprowadzenie}

W obliczu braku znaczących sukcesów w poszukiwaniach nowych złóż ropy naftowej wydaje się, że ochrona istniejących zasobów polegająca na maksymalizacji stopnia ich sczerpania stanowi sprawę nadrzędną dla przyszłości krajowego górnictwa naftowego. Efektywna realizacja tego zagadnienia jest możliwa jedynie z wykorzystaniem odpowiednio dostosowanych metod wspomagania wydobycia ropy (ang. enhanced oil recovery, EOR). Niezwłoczne wprowadzenie metod EOR na krajowych złożach nie tylko jest niezbędne dla ochrony krajowych zasobów węglowodorów, ale również może być korzystne z punktu widzenia ochrony środowiska. W EOR wykorzystuje się problematyczne dla środowiska naturalnego płyny, tj.: towarzyszącą wydobyciu ropy solankę złożową, wodę technologiczną, $\mathrm{CO}_{2}$ /gazy kwaśne, spalinowe czy poprocesowe, które bezpiecznie i trwale deponowane są w szczelnych strukturach geologicznych. Co więcej, wzmożone i globalne działania na rzecz wprowadzenia tzw. Zielonego Ładu, zakładające aktywną walkę o ograniczenie wpływu gospodarki UE na środowisko, polegającą w szczególności na ograniczeniu emisji $\mathrm{CO}_{2}$ do atmosfery, będą zapewne faworyzować wszelkie projekty związane z utylizacją $\mathrm{CO}_{2}$. Można się spodziewać, że w niedalekiej przyszłości projekty $\mathrm{CO}_{2}$-EOR będą uzyskiwać coraz większe wsparcie zarówno ze strony regulacyjnej, jak i odpowiednich instrumentów finansowych. Można przypuszczać, że rozwój technologii wychwytywania $\mathrm{CO}_{2}$ sprawi, że gaz ten będzie bardziej dostępny i tańszy w pozyskaniu, a co za tym idzie - bardziej konkurencyjny do wykorzystania w procesach wspomagania wydobycia. Zatłaczanie gazu w procesach EOR wiąże się z wystąpieniem niekorzystnego współczynnika mobilności związanego z dużą różnicą lepkości między zatłaczanym gazem a obecną w złożu ropą. Prowadzi to do destabilizacji frontu wypierania, tworzenia się języków gazowych i przedwczesnego przebicia zatłaczanego płynu do odwiertów wydobywczych. Powstają strefy nasycone ropą i nieobjęte zasięgiem frontu wypierania - będące przyczyną stosunkowo niskiego współczynnika sczerpania. Jedną z bardziej interesujących metod wspomagania wydobycia z dojrzałych złóż ropy naftowej, która pozwala na przeciwdziałanie ww. niekorzystnym zjawiskom, jest naprzemienne zatłaczanie wody i gazu (ang. water alternating gas, WAG). Odpowiednio zoptymalizowane cykliczne zatłaczanie wody z gazem pozwala na skuteczną kontrolę współczynnika mobilności gazu, poprawiając tym samym efektywność procesu wypierania ropy. Opracowanie optymalnej strategii eksploatacji jest zasadniczym aspektem prowadzenia efektywnego wydobycia (Lubaś et al., 2019).

Wstępną ocenę efektywności ekonomicznej metody WAG przeprowadzono na podstawie wyników badań eksperymentalnych zrealizowanych w ramach pracy doktorskiej jednego z autorów artykułu (Wojnicki, 2020b). Kwestie dotyczące podstaw teoretycznych metody WAG, charakterystyki poszczególnych jej wariantów oraz przykładów zastosowań złożowych zostały szczegółowo przedstawione we wcześniejszych publikacjach tego autora obejmujących omawianą tematykę (Wojnicki, 2017a, 2017b, 2019, 2020a, Wojnicki et al., 2020) i nie są poruszane w niniejszym artykule.

\section{Badania eksperymentalne procesu WAG}

Badania laboratoryjne są uznawane za podstawę potwierdzenia słuszności koncepcji wspomagania wydobycia ropy z danego złoża oraz za narzędzie podejmowania kolejnych decyzji

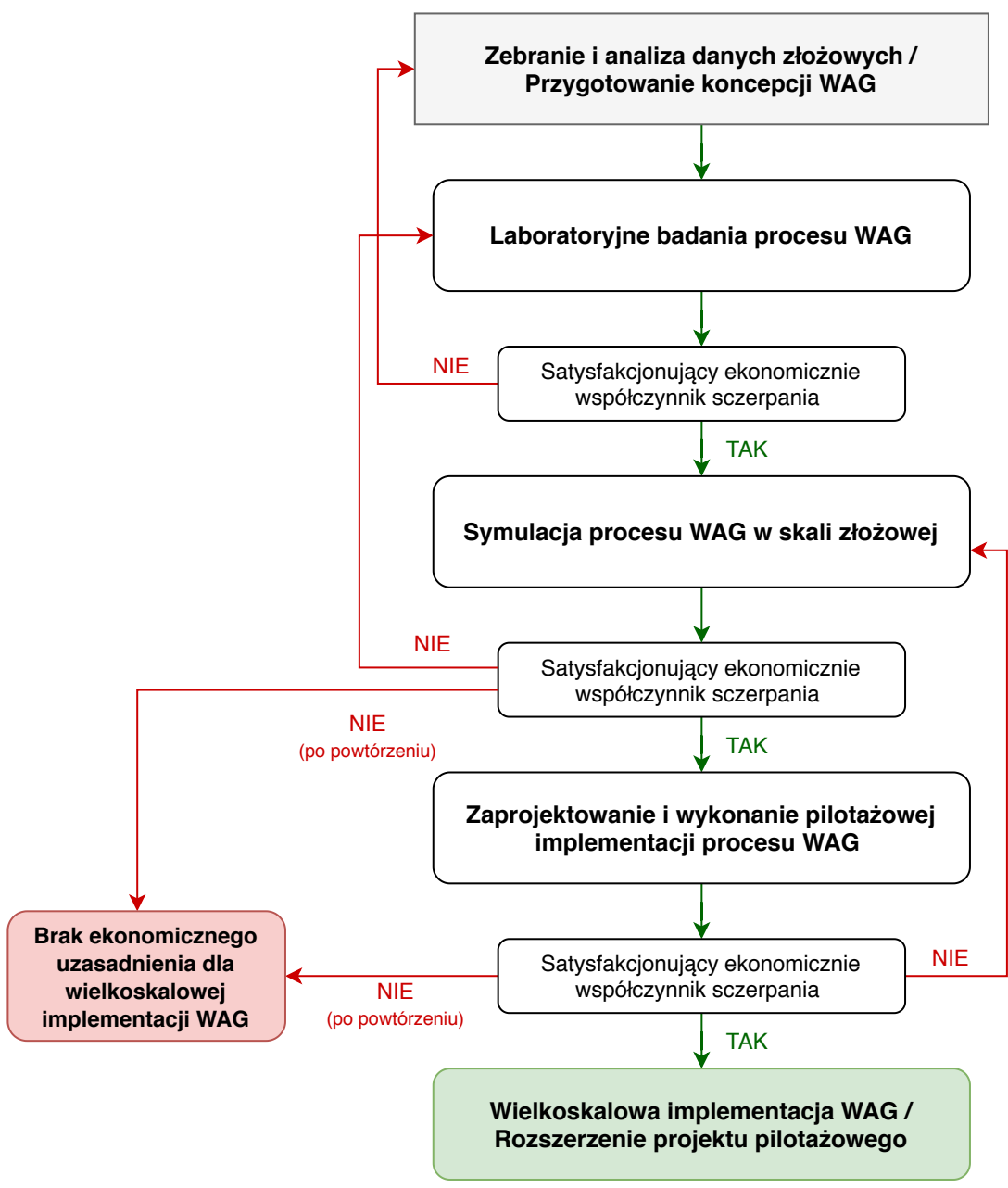

Rys. 1. Typowy schemat postępowania przy realizacji pełnoskalowego projektu WAG (Belazreg et al., 2019)

Fig. 1. Typical workflow for a full-scale WAG project (Belazreg et al., 2019) 
w ciągu logicznym implementacji procesu EOR. Dzięki poznaniu potencjalnego wzrostu skuteczności wypierania ropy są one wykorzystywane do minimalizacji ryzyka zastosowania danego procesu w skali złożowej (Moreno et al., 2018). Pozycję badań laboratoryjnych w typowym schemacie realizacji pełnoskalowego projektu WAG przedstawiono na rysunku 1.

Począwszy od pierwszych testów w późnych latach 60 . opublikowano setki prac eksperymentalnych dotyczących wielu czynników i mechanizmów wpływających na efektywność procesu WAG, takich jak: parametry złożowe, np. zwilżalność skał zbiornikowych (Huang i Holm, 1988; Skauge i Aarra, 1993) i ich heterogeniczność (Surguchev et al., 1992; van Lingen et al., 1996; Hoare i Coll, 2018); właściwości zatłaczanych płynów, np. zasolenie (Zolfaghari et al., 2013; Al-Shalabi et al., 2014) czy rodzaj zatłaczanego gazu (Kulkarni i Rao, 2005; Ghafoori et al., 2012); parametry procesowe WAG, np. stosunek zatłaczanych płynów (ang. WAG ratio) (Al-Shuraiqi et al., 2003; Juanes i Blunt, 2007), liczba cykli, wielkości zatłaczanych porcji (Rahimi et al., 2017), wybór odpowiedniego momentu rozpoczęcia zatłaczania (Jiang et al.,

Tabela 1. Skład gazów ziemnych wykorzystanych w procesie WAG

Table 1. Composition of natural gases used in the WAG process

\begin{tabular}{|c|c|c|}
\hline \multirow[t]{2}{*}{ Składnik } & \multicolumn{2}{|c|}{$\begin{array}{c}\text { Zawartość } \\
{[\% \mathrm{~mol} / \mathrm{mol}]}\end{array}$} \\
\hline & GM & GK \\
\hline metan & 28,66 & 5,63 \\
\hline etan & 4,73 & 0,82 \\
\hline propan & 2,56 & 0,68 \\
\hline i-butan & 0,44 & 0,16 \\
\hline n-butan & 0,87 & 0,32 \\
\hline neo-pentan & 0,003 & 0,00 \\
\hline i-pentan & 0,25 & 0,15 \\
\hline n-pentan & 0,23 & 0,14 \\
\hline$\Sigma-\mathrm{C}_{6}$ & 0,16 & 0,17 \\
\hline$\Sigma-\mathrm{C}_{7}$ & 0,06 & 0,09 \\
\hline$\Sigma-\mathrm{C}_{8}$ & 0,02 & 0,02 \\
\hline$\Sigma-\mathrm{C}_{9}$ & 0,00 & 0,00 \\
\hline$\Sigma-\mathrm{C}_{10}$ & n.s. & 0,00 \\
\hline$\Sigma-\mathrm{C}_{11}$ & n.s. & n.s. \\
\hline$\Sigma-\mathrm{C}_{12}$ & n.s. & n.s. \\
\hline dwutlenek węgla & 0,28 & 1,19 \\
\hline azot & 58,48 & 86,85 \\
\hline wodór & n.o. & 1,05 \\
\hline siarkowodór & 3,26 & 2,73 \\
\hline hel & 0,01 & n.s. \\
\hline Razem: & 100,000 & 100,00 \\
\hline
\end{tabular}

n.s. - nie stwierdzono

n.o. - nie oznaczono
2012), dobór wydatków zatłaczania (Jafari, 2014) itd. Wiele z opublikowanych dotychczas prac pozwoliło zwiększyć efektywność WAG oraz wskazało kierunek i konieczność dalszego rozwoju metody. Pilotażowe badania laboratoryjne prowadzone w INiG - PIB (Wojnicki, 2017a), dotyczące zastosowania WAG w warunkach krajowych, zaowocowały realizacją kolejnych prac badawczych (Wojnicki et al., 2019, 2020), których wyniki wykorzystano do przeprowadzenia wstępnej oceny efektywności ekonomicznej.

Skuteczność poszczególnych wariantów WAG, wyróżniających się typem zatłaczanego gazu, ciśnieniem zatłaczania i stosunkiem zatłaczanej wody do gazu, określono na podstawie eksperymentów wypierania ropy naftowej (ang. coreflooding). W celu możliwie pełnego odwzorowania warunków złożowych eksperymenty przeprowadzono na fizycznym modelu złoża zbudowanym z długich rdzeni wiertniczych (oryginalnej skały zbiornikowej), z odtworzeniem nasycenia ośrodka porowatego oryginalnymi płynami złożowymi i zachowaniem zadanych warunków termobarycznych.

W badaniach eksperymentalnych przetestowano zatłaczanie czterech różnych gazów, tj. $\mathrm{CO}_{2}$, gazu kwaśnego odpowiadającego produktowi z regeneracji aminy (mieszanina

Tabela 2. Zestawienie badań eksperymentalnych wykorzystanych w ocenie

Table 2. Summary of experimental studies used in the evaluation

\begin{tabular}{|c|c|c|c|c|}
\hline \multirow{2}{*}{ Lp. } & \multirow{2}{*}{ Gaz } & \multirow{2}{*}{$\begin{array}{c}\text { Sposób } \\
\text { zatlaczania }\end{array}$} & Ciśnienie & RF po $1,2 \mathrm{PV}$ \\
\hline & & & [bar] & {$[\%]$} \\
\hline 1 & - & CWI & 270 & 54,0 \\
\hline 2 & \multirow{5}{*}{$\delta^{N}$} & CGI & 270 & 82,5 \\
\hline 3 & & WAG $1: 1$ & 270 & 79,8 \\
\hline 4 & & WAG $2: 1$ & 270 & 70,2 \\
\hline 5 & & WAG $1: 2$ & 270 & 82,9 \\
\hline 6 & & WAG $1: 1$ & 170 & 65,1 \\
\hline 7 & \multirow{5}{*}{$\sum_{\circlearrowright}$} & CGI & 270 & 43,0 \\
\hline 8 & & WAG $1: 1$ & 270 & 64,0 \\
\hline 9 & & WAG $2: 1$ & 270 & 56,8 \\
\hline 10 & & WAG $1: 2$ & 270 & 69,3 \\
\hline 11 & & WAG $1: 1$ & 170 & 56,9 \\
\hline 12 & \multirow{5}{*}{$\begin{array}{l}\mathcal{N}_{N} \\
\boldsymbol{I}^{+} \\
+ \\
0^{N}\end{array}$} & CGI & 270 & 81,2 \\
\hline 13 & & WAG $1: 1$ & 270 & 69,5 \\
\hline 14 & & WAG $2: 1$ & 270 & 65,3 \\
\hline 15 & & WAG $1: 2$ & 270 & 72,6 \\
\hline 16 & & WAG $1: 1$ & 170 & 60,7 \\
\hline 17 & \multirow{5}{*}{ 过 } & CGI & 270 & 37,0 \\
\hline 18 & & WAG $1: 1$ & 270 & 72,1 \\
\hline 19 & & WAG $2: 1$ & 270 & 58,1 \\
\hline 20 & & WAG $1: 2$ & 270 & 63,4 \\
\hline 21 & & WAG $1: 1$ & 170 & 62,8 \\
\hline
\end{tabular}


$\left.\mathrm{CO}_{2} / \mathrm{H}_{2} \mathrm{~S}, 70 / 30 v / v\right)$ oraz zaazotowanych i zasiarczonych gazów ziemnych GM i GK. Skład gazów ziemnych wykorzystanych w zatłaczaniu WAG przestawiono w tabeli 1.

Dla celów porównania skuteczności metody WAG wykonano eksperymenty zatłaczania samej wody (CWI) i samego gazu (CGI). Eksperymenty prowadzono przy ciśnieniu bliskiemu złożowemu (270 bar) oraz o 100 bar niższym (170 bar). Wielkość zatłaczanej porcji płynu (ang. slug size) w cyklu WAG, na podstawie wcześniej prowadzonych eksperymentów (Wojnicki, 2017a; Wojnicki et al., 2017), ustalono na 0,2 PV HC $_{\text {(objętości }}$ porowej dostępnej dla węglowodorów). W obliczeniach wykorzystano wyniki 21 eksperymentów wypierania ropy, których podstawową charakterystykę przedstawiono w tabeli 2.

\section{Wstępna ocena efektywności ekonomicznej}

Postęp technologiczny i intensyfikacja prac nad metodami EOR, których wykorzystanie powinno być uwzględnione już na wczesnym etapie zagospodarowania złoża, sprawiają, że ekonomicznie uzasadnione staje się uzyskiwanie coraz większych współczynników sczerpania. Dokonanie właściwego wyboru strategii EOR często jest kluczowym elementem w racjonalnym i efektywnym gospodarowaniu zasobami węglowodorów. W zależności od sytuacji złożowej i oczekiwanych efektów optymalizacja wydobycia sprowadza się zwykle do maksymalizacji kluczowych parametrów, tj. wydatku dobowego, całkowitego wydobycia, NPV itp.

Wyniki badań eksperymentalnych potwierdzają, że na efektywność WAG wpływa w dużej mierze rodzaj (skład) wykorzystywanego gazu, jego udział w strumieniu zatłaczanych płynów, ciśnienie zatłaczania oraz charakter ośrodka porowatego. Biorąc pod uwagę kryterium współczynnika odropienia, najbardziej efektywnym gazem w analizowanych eksperymentach okazał się dwutlenek węgla i jego mieszanina z siarkowodorem (tabela 1). Należy jednak mieć na uwadze, że koszty związane z pozyskaniem danego gazu w ilości wymaganej do zatłoczenia mogą w sposób krytyczny wpływać na zasadność wykorzystania danego wariantu. Dlatego też podjęto próbę wstępnej oceny efektywności procesu WAG z uwzględnieniem kosztów zatłaczanych mediów.

Koszt $\mathrm{CO}_{2}$ oszacowano na podstawie danych literaturowych (Herzog, 2011; Lubaś et al., 2015; Núñez-López i Moskal, 2019) z uwzględnieniem zakupu na rynku po cenie odpowiadającej kosztom projektów demonstracyjnych wraz z dostawą na złoże $(70 \$ / t)$. Koszt mieszaniny $\mathrm{CO}_{2} \mathrm{i}_{2} \mathrm{~S}$ oszacowano na podstawie przyjętej ceny $\mathrm{CO}_{2}$, zakładając, że pozyskanie $\mathrm{H}_{2} \mathrm{~S}$ będzie bezpłatne (gaz odpadowy z aminowej instalacji odsiarczania). Koszty zatłaczania gazów przeliczono do objętości wymaganych w warunkach złożowych z wykorzystaniem parametrów określonych za pomocą oprogramowania PVTsim (tabela 3).

Koszty gazów węglowodorowych obliczono na podstawie ich wartości opałowej w odniesieniu do spotowej ceny gazu ziemnego (1,63 \$/mln Btu) z czerwca 2020 r. (U.S. Energy Information Administration, 2020). Należy jednak mieć na uwadze, że takie podejście w przypadku, gdy mamy do czynienia z gazami wysokozaazotowanymi, może prowadzić do przeszacowania ich kosztów. Szczególnie gdy dysponentem gazów jest operator wprowadzający proces zatłaczania, a parametry

Tabela 3. Parametry zatłaczanych gazów w warunkach złożowych $\left(\mathrm{T}=126^{\circ} \mathrm{C}\right)$

Table 3. Parameters of injected gases in reservoir conditions $\left(\mathrm{T}=126^{\circ} \mathrm{C}\right)$

\begin{tabular}{|c|c|c|c|c|c|c|}
\hline \multirow{2}{*}{ Gaz } & \multicolumn{2}{|c|}{$Z^{(1)}$} & \multicolumn{2}{|c|}{$B_{g}{ }^{(2)}$} & \multicolumn{3}{c|}{$E_{g}{ }^{(3)}$} \\
\cline { 2 - 7 } & \multicolumn{2}{|c|}{$[-]$} & \multicolumn{4}{|c|}{$\left[\mathbf{m}^{3} / \mathbf{m}^{3}\right]$} \\
\cline { 2 - 7 } & $\mathbf{1 7 0}$ bar & $\mathbf{2 7 0} \mathbf{~ b a r}$ & $\mathbf{1 7 0} \mathbf{b a r}$ & $\mathbf{2 7 0}$ bar & $\mathbf{1 7 0}$ bar & $\mathbf{2 7 0}$ bar \\
\hline \hline $\mathrm{GM}$ & 1,0366 & 1,0921 & 0,00904 & 0,00599 & 110,662 & 166,815 \\
\hline $\mathrm{GK}$ & 1,0663 & 1,1257 & 0,00930 & 0,00618 & 107,575 & 161,845 \\
\hline $\mathrm{CO}_{2}$ & 0,7529 & 0,7413 & 0,00656 & 0,00407 & 152,353 & 245,746 \\
\hline $\mathrm{CO}_{2} / \mathrm{H}_{2} \mathrm{~S}$ & 0,6972 & 0,6873 & 0,00608 & 0,00377 & 164,524 & 265,075 \\
\hline
\end{tabular}

${ }^{1}$ współczynnik ściśliwości gazu; ${ }^{2}$ współczynnik objętościowy gazu; ${ }^{3}$ współczynnik ekspansji gazu

Tabela 4. Wyliczenie cen jednostkowych zatłaczanych gazów

Table 4. Calculation of unit prices for injected gases

\begin{tabular}{|c|c|c|c|c|c|c|c|c|c|c|}
\hline Gaz & $\boldsymbol{Q} \boldsymbol{w}^{(1)}$ & $\boldsymbol{M}^{(2)}$ & $\boldsymbol{V}_{t}^{(3)}$ & $\boldsymbol{\rho} \boldsymbol{n}^{(4)}$ & $V_{\boldsymbol{m l n} \boldsymbol{B} t \boldsymbol{u}^{(5)}}$ & $\boldsymbol{m}_{\boldsymbol{m l n} B t u^{(6)}}$ & Cena $[t]$ & Cena $\left[\mathrm{m}^{3}\right]$ & $\begin{array}{l}\text { Cena m }{ }^{3} \\
270 \text { bar }\end{array}$ & $\begin{array}{l}\text { Cena m } \\
170 \text { bar }^{3}\end{array}$ \\
\hline & {$\left[\mathrm{Btu} / \mathbf{m}^{3]}\right.$} & [g/mol] & {$\left[\mathbf{m}^{3}\right]$} & {$\left[\mathrm{kg} / \mathrm{m}^{3}\right]$} & {$\left[\mathbf{m}^{3}\right]$} & {$[\mathrm{kg}]$} & \multicolumn{4}{|c|}{ [\$] } \\
\hline GM & 15620,03 & 26,65 & 840,3 & 1,19 & 64,02 & 76,18 & $11,27^{(7)}$ & 0,014 & 2,29 & 1,56 \\
\hline GK & 4492,65 & 27,99 & 874,2 & 1,16 & 222,59 & 258,2 & $9,30^{(7)}$ & 0,011 & 1,72 & 1,14 \\
\hline $\mathrm{CO}_{2}$ & - & 44,0 & 556,1 & 1,97 & - & - & $70^{(8)}$ & 0,125 & 30,93 & 19,18 \\
\hline $\mathrm{CO}_{2} / \mathrm{H}_{2} \mathrm{~S}$ & - & 41,0 & 596,8 & 1,71 & - & - & $49^{(8)}$ & 0,082 & 21,76 & 13,51 \\
\hline
\end{tabular}

wartość opałowa; ${ }^{2}$ masa molowa; ${ }^{3}$ objętość tony gazu w warunkach normalnych; ${ }^{4}$ gęstość gazu w warunkach normalnych; ${ }^{5}$ objętość gazu o energii $1 \mathrm{mln}$ Btu w warunkach normalnych; ${ }^{6}$ masa gazu o energii $1 \mathrm{mln} \mathrm{Btu} ;{ }^{7}$ wartość wyliczona na podstawie kaloryczności gazu w odniesieniu do ceny spotowej; ${ }^{8}$ wartość przyjęta arbitralnie na podstawie analizy literatury 
kaloryczne gazu są na tyle słabe, że trudno go dostosować do wymogów przemysłowej sieci gazu zaazotowanego.

Oszacowane koszty zatłaczanych gazów przyjmują wartości w zakresie 1-31 \$/m $\mathrm{m}^{3}$ gazu w warunkach złożowych i zależą od rodzaju gazu, jak i warunków ciśnieniowych zatłaczania. By przeanalizować efektywność ekonomiczną przebadanych eksperymentalnie wariantów, oszacowano ceny gazu w dwóch ciśnieniach badawczych, tj. 270 bar i 170 bar. W tabeli 4 przedstawiono wyniki wyliczeń szacunkowych cen zatłaczanych gazów oraz parametry wykorzystane do ich wykonania.

Cenę zatłaczanej wody określono na poziomie $0,3 \$ / \mathrm{m}^{3}$, uwzględniając realne koszty opłat środowiskowych wykorzystania wody studziennej do celów technologicznych w jednej z polskich kopalni ropy naftowej. Biorąc pod uwagę rozszerzalność cieplną wody, za koszt metra sześciennego w warunkach złożowych przyjęto 0,29 \$. Do celów przeliczeń założono, że oddziaływaniu procesu wspomagania wydobycia poddany będzie wolumen $1000 \mathrm{~m}^{3}$ objętości porowej dostępnej dla węglowodorów $\left(\mathrm{PV}_{\mathrm{HC}}\right)$, a całkowita objętość zatłaczanych płynów w procesie wyniesie $1,2 \mathrm{PV}_{\mathrm{HC}}$.

Określenie efektywności ekonomicznej poszczególnych wariantów WAG polegało na przeliczeniu wartości współczynnika odropienia (RF\%) uzyskanego po zatłoczeniu $1,2 \mathrm{PV}_{\mathrm{HC}}$ mediów $\mathrm{w}$ danym wariancie na przychody ze sprzedaży ropy przy założeniu ceny 40 \$ za baryłkę (U.S. Energy Information Administration, 2020), czyli średniej ceny ropy
Brent w czerwcu 2020 roku. Koszty zatłaczania obliczono na podstawie cen jednostkowych zatłaczanych mediów (tabela 4) oraz stosunku objętości zatłoczonych mediów w danym wariancie.

Dla bardziej przejrzystego przedstawienia kosztów związanych z zastosowaniem danego wariantu przedstawiono je w postaci wydatków poniesionych na wydobycie jednej baryłki ropy. Obliczony zysk, czyli przychód ze sprzedaży wolumenu wydobytej ropy pomniejszony o koszt związany z pozyskaniem mediów do zatłaczania, przedstawiono również w odniesieniu do efektywności nawadniania (CWI). Wyniki przeliczeń dla wstępnej oceny efektywności ekonomicznej poszczególnych wariantów procesu WAG przedstawiono w tabeli 5.

Najwyższymi kosztami w przeliczeniu na baryłkę wydobytej ropy cechują się warianty WAG z wykorzystaniem dwutlenku węgla (2,85-7,63 \$/bbl) oraz gazu kwaśnego (2,17-2,61 \$/bbl). Zdecydowanie niższym kosztem pozyskania baryłki charakteryzują się warianty WAG z wykorzystaniem wysokozaazotowanych gazów GK $(0,16-0,60$ \$/bbl) oraz GM (0,52-1,88 \$/bbl). Najniższym kosztem procesu w przeliczeniu na baryłkę, dla każdego z gazów, odznacza się wariant z obniżonym ciśnieniem zatłaczania (170 bar). Jest to oczywiście związane ze współczynnikiem objętościowym gazu, wpływającym na niższy koszt wolumenu gazu w warunkach złożowych przy niższym ciśnieniu. Najniższy koszt zatłaczanych mediów przy obniżonym ciśnieniu zatłaczania nie idzie w parze z najwyższym zyskiem,

Tabela 5. Wstępna ocena efektywności ekonomicznej procesu WAG

Table 5. A preliminary assessment of the economic efficiency of the WAG process

\begin{tabular}{|c|c|c|c|c|c|c|c|c|c|c|}
\hline \multirow{2}{*}{ Lp. } & \multirow{2}{*}{ Gaz } & \multirow{2}{*}{$\begin{array}{c}\text { Vo } \\
{[\text { bbl] }}\end{array}$} & \multirow{2}{*}{$\begin{array}{c}\text { Przychód } \\
{[\$]}\end{array}$} & \multicolumn{4}{|c|}{ Koszty [\$] } & \multicolumn{3}{|c|}{ Zysk } \\
\hline & & & & Woda & Gaz & Razem & Koszt na baryłkę & P-K [\$] & $>\mathrm{CWI}[\$]$ & $>$ CWI $[\%]$ \\
\hline 1 & - & 3396,6 & 135864 & 342,0 & 0,0 & 342,0 & 0,10 & 135522 & 0 & - \\
\hline 2 & \multirow{5}{*}{$\overbrace{}^{2}$} & 4862,2 & 194487 & 0,0 & 37116,0 & 37116,0 & 7,63 & 157371 & 21849 & 16,1 \\
\hline 3 & & 4975,4 & 199016 & 171,0 & 18558,0 & 18729,0 & 3,76 & 180287 & 44765 & 33,0 \\
\hline 4 & & 4415,6 & 176623 & 273,6 & 14846,4 & 15120,0 & 3,42 & 161503 & 25981 & 19,2 \\
\hline 5 & & 5214,4 & 208576 & 136,8 & 29692,8 & 29829,6 & 5,72 & 178747 & 43225 & 31,9 \\
\hline 6 & & 4094,8 & 163792 & 171,0 & 11508,0 & 11679,0 & 2,85 & 152113 & 16591 & 12,2 \\
\hline 7 & \multirow{5}{*}{$\sum_{U}$} & 2704,7 & 108188 & 0,0 & 5096,7 & 5096,7 & 1,88 & 103091 & -32431 & $-23,9$ \\
\hline 8 & & 4025,6 & 161024 & 171,0 & 2548,3 & 2719,3 & 0,68 & 158305 & 22783 & 16,8 \\
\hline 9 & & 3572,72 & 142909 & 273,6 & 2038,7 & 2312,3 & 0,65 & 140597 & $5 d 75$ & 37 \\
\hline 10 & & 4358,97 & 174359 & 136,8 & 4077,3 & 4214,1 & 0,97 & 170145 & $34 \frac{1623}{3}$ & 25,5 \\
\hline 11 & & 3579,01 & 143160 & 171,0 & 1690,5 & 1861,5 & 0,52 & 141299 & 5777 & 4,3 \\
\hline 12 & \multirow{5}{*}{$\begin{array}{l}\tilde{N}_{N} \\
\boldsymbol{I}^{2} \\
+ \\
0^{N}\end{array}$} & 4887,33 & 195493 & 0,0 & 26115,3 & 26115,3 & 5,34 & 169378 & 33856 & 25,0 \\
\hline 13 & & 4371,55 & 174862 & 171,0 & 13057,7 & 13228,7 & 3,03 & 161633 & 26111 & 6,3 \\
\hline 14 & & 4107,37 & 164295 & 273,6 & 10446,1 & 10719,7 & 2,61 & 153575 & 18053 & 13,3 \\
\hline 15 & & 4566,54 & 182662 & 136,8 & 20892,3 & 21029,1 & 4,61 & 161633 & 26111 & 19,3 \\
\hline 16 & & 3818,03 & 152721 & 171,0 & 8104,5 & 8275,5 & 2,17 & 144446 & 8924 & 6,6 \\
\hline 17 & \multirow{5}{*}{$\stackrel{v}{0}$} & 2327,3 & 93092 & 0,0 & 1402,4 & 1402,4 & 0,60 & 91690 & $-43,832$ & $-32,3$ \\
\hline 18 & & 4535,09 & 181404 & 171,0 & 701,2 & 872,2 & 0,19 & 180531 & 45009 & $27: 8$ \\
\hline 19 & & 3654,49 & 146180 & 273,6 & 561,0 & 834,6 & 0,23 & 145345 & 9823 & 7,2 \\
\hline 20 & & 3987,86 & 159514 & 136,8 & 1121,9 & 1258,7 & 0,32 & 158256 & 22734 & 16 \\
\hline 21 & & 3950,12 & 158005 & 171,0 & 466,1 & 637,1 & 0,16 & 157368 & 21846 & 16 \\
\hline
\end{tabular}




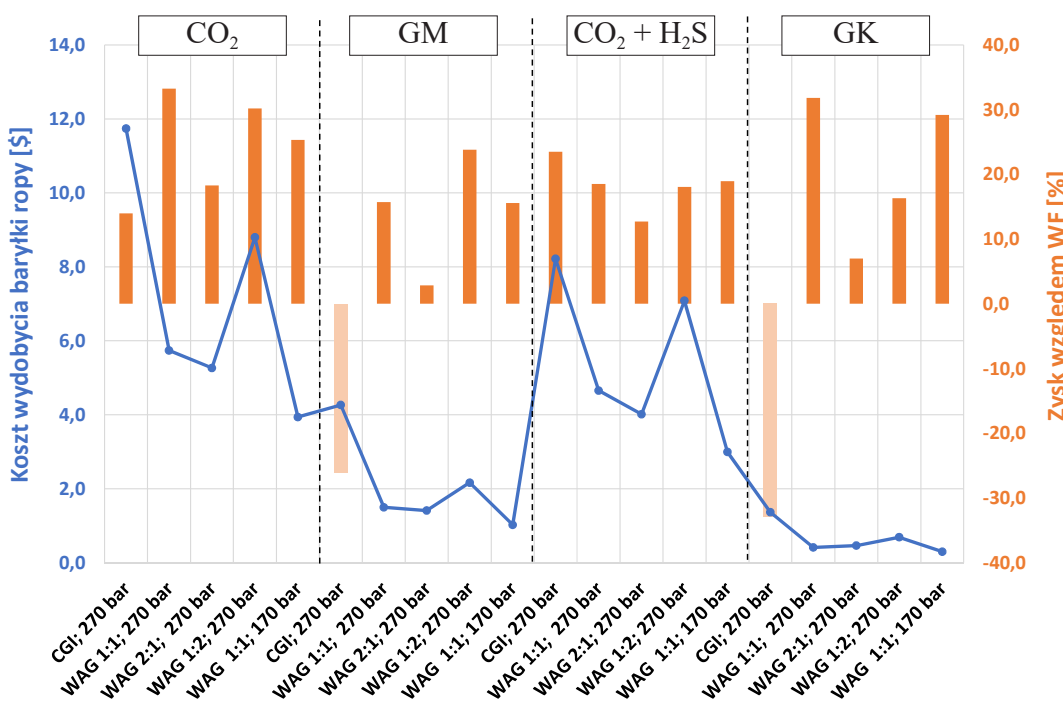

Rys. 2. Porównanie kosztu wydobycia baryłki ropy i procentowego zysku względem CWI

Fig. 2. Comparison of the production cost of a barrel of oil and the percentage profit in the relation to the CWI

gdyż w przypadku każdego z przebadanych gazów współczynnik odropienia jest wtedy zauważalnie niższy. Najwyższą wartość zysku względem CWI, wynoszącą 33,2\%, odnotowano dla gazu GK i wariantu WAG 1 : 1 (270 bar). Jest to niemal identyczny wynik, jaki otrzymano dla tego samego wariantu WAG z wykorzystaniem dwutlenku węgla.

Porównując te dwa warianty pod względem współczynnika odropienia, widać, że efektywniejszy jest WAG- $\mathrm{CO}_{2}$, jednak biorąc pod uwagę wypracowany zysk, bardziej optymalny byłby wybór wariantu WAG-GK, w którym decydującą rolę odgrywa niski koszt zatłaczanego gazu. Prowadząc dalszą analizę otrzymanych wartości zysku względem efektywności CWI (rys. 2), możemy zauważyć, że zatłaczanie CGI w przypadku gazów węglowodorowych jest zupełnie nieopłacalne, gdyż zysk przyjmuje wartości ujemne. Rozkład wartości zysku wśród wariantów $\mathrm{z}$ dwutlenkiem węgla i gazem kwaśnym $\left(\mathrm{CO}_{2} / \mathrm{H}_{2} \mathrm{~S}\right)$ jest mniej zróżnicowany w porównaniu do gazów węglowodorowych (rys. 2). Mimo że poza pojedynczymi wariantami, tj. WAG $1: 1$ (270 bar) w przypadku GK oraz WAG $1: 2$ (270 bar), zaazotowane gazy węglowodorowe są generalnie mniej efektywne pod względem ekonomicznym (przy przyjętych założeniach), to niższe koszty sprawiają, że ich użycie może być bardziej adekwatne w czasie niestabilnych i niskich cen ropy.

\section{Podsumowanie}

Wstępna analiza opłacalności wykazała, że mimo znacząco niższej skuteczności zaazotowanych gazów ziemnych przy wspomaganiu wydobycia ropy (w kontekście ostatecznego stopnia sczerpania) - ich zastosowanie może być w pełni uzasadnione pod względem ekonomicznym. Pomimo niższych wartości współczynnika odropienia dla WAG $1: 1$ $\mathrm{GK}$ - w odniesieniu do $\mathrm{CO}_{2}$ - jest on najbardziej efektywny pod względem ekonomicznym, co związane jest ze zdecydowanie niższymi kosztami pozyskania gazu. Dobór optymalnego pod względem ekonomicznym wariantu wspomagania wydobycia zależy w dużej mierze od przyjętych (aktualnych) kosztów związanych z pozyskaniem zatłaczanych mediów oraz od koniunktury na rynkach naftowych. Należy mieć na uwadze, że przeprowadzona analiza, choć ukazuje rozdzielność między skutecznością wypierania wyrażoną współczynnikiem odropienia i efektywnością ekonomiczną wynikającą z ponoszonych kosztów, jest oparta jedynie na uproszczonych założeniach, związanych z charakterem prac eksperymentalnych. Uzyskanie dokładniejszych prognoz wymaga wykorzystania danych dotyczących skuteczności danego wariantu z uwzględnieniem budowy przestrzennej złoża, założeń i ograniczeń wynikających z parametrów eksploatacyjnych itp. Niezbędne do tego jest przeprowadzenie dynamicznych symulacji złożowych. Dobór optymalnego ekonomicznie wariantu w rzeczywistej sytuacji wymagałby użycia zaawansowanych narzędzi analitycznych biorących pod uwagę zdecydowanie większą liczbę parametrów, trendów i prognoz makroekonomicznych. W rozpatrywanym przypadku krajowych złóż ropy naftowej w dolomicie głównym kluczowym argumentem przemawiającym za wykorzystaniem gazu GK jest jego łatwa dostępność. W jednym z przypadków odległość między złożem wysokozaazotowanego gazu ziemnego a złożem ropy naftowej wynosi około $10 \mathrm{~km}$. Dodatkowym argumentem są spore zasoby wysokozaazotowanego gazu ziemnego, które według wstępnych ustaleń dla jednego ze złóż wynoszą ponad $10 \mathrm{mld} \mathrm{m}^{3}$.

Artykuł powstał na podstawie pracy statutowej pt. Optymalizacja procesu naprzemiennego zattaczania wody i gazu dla weglanowego złoża ropy naftowej - praca INiG na zlecenie MNiSW; nr zlecenia: 0064/KB/2020, nr archiwalny: DK-4100-0052/2020.

\section{Literatura}

Al-Shalabi E.W., Sepehrnoori K., Pope G.A., 2014. Modeling the Combined Effect of Injecting Low Salinity Water and Carbon Dioxide on Oil Recovery from Carbonate Cores. International Petroleum Technology Conference. DOI: 10.2523/IPTC-17862-MS.

Al-Shuraiqi H.S., Muggeridge A.H., Grattoni C.A., 2003. Laboratory Investigations of First Contact Miscible Wag Displacement: The Effects of Wag Ratio and Flow Rate. Society of Petroleum Engineers. DOI: 10.2118/84894-MS.

Belazreg L., Mahmood S.M., Aulia A., 2019. Novel approach for predicting water alternating gas injection recovery factor, Journal of Petroleum Exploration and Production Technology, 9(4): 28932910. DOI: 10.1007/s13202-019-0673-2. 
Ghafoori A., Shahbazi K., Darabi A., Soleymanzadeh A., Abedini A., 2012. The experimental investigation of nitrogen and carbon dioxide water-alternating-gas injection in a carbonate reservoir. Petroleum Science and Technology, 30(11): 1071-1081. DOI: 10.1080/10916461003681745.

Herzog H.J., 2011. Scaling up carbon dioxide capture and storage: From megatons to gigatons. Energy Economics, 33(4): 597-604. DOI: 10.1016/j.eneco.2010.11.004.

Hoare G., Coll C., 2018. Effect of small/medium scale reservoir heterogeneity on the effectiveness of water, gas and water alternating gas WAG injection. Society of Petroleum Engineers. DOI: 10.2118/190855-ms.

Huang E.T.S., Holm L.W., 1988. Effect of WAG injection and rock wettability on oil recovery during CO2 flooding. Society of Petroleum Engineers. DOI: 10.2118/15491-PA.

Jafari M., 2014. Laboratory study for water, gas and wag injection in lab scale and core condition. Petroleum \& Coal, 56(2): 175-181.

Jiang H., Nuryaningsih L., Adidharma H., 2012. The study of timing of cyclic injections in miscible $\mathrm{CO}_{2}$ WAG. Society of Petroleum Engineers. DOI: 10.2118/153792-MS.

Juanes R., Blunt M.J., 2007. Impact of viscous fingering on the prediction of optimum WAG ratio. Society of Petroleum Engineers. DOI: 10.2118/99721-PA.

Kulkarni M.M., Rao D.N., 2005. Experimental investigation of miscible and immiscible Water-Alternating-Gas (WAG) process performance. Journal of Petroleum Science and Engineering, 48(1-2): 1-20. DOI: 10.1016/j.petrol.2005.05.001.

van Lingen P.P., Barzanji O.H.M., van Kruijsdijk C.P.J.W., 1996. WAG Injection to Reduce Capillary Entrapment in SmallScale Heterogeneities. Society of Petroleum Engineers. DOI: 10.2118/36662-MS.

Lubaś J., Stopa J., Warnecki M., Wojnicki M., 2019. Możliwości zastosowania zaawansowanych metod wspomagania wydobycia ropy naftowej ze złóż dojrzałych. Nafta-Gaz, 1:24-28. DOI: 10.18668/NG.2019.01.04.

Lubaś J., Szott W., Wójcicki A., 2015. Wspomaganie wydobycia ropy naftowej i gazu ziemnego z polskich złóż z wykorzystaniem $\mathrm{CO}_{2}$ i jego równoczesną sekwestracją. Biuletyn Państwowego Instytutu Geologicznego, 465: 45-46.

Moreno J.E., Flew S., Gurpinar O., Liu Y., Gossuin J., 2018. Effective Use of Laboratory Measurements on Eor Planning. Offshore Technology Conference. DOI: 10.4043/29057-MS.

Núñez-López V., Moskal E., 2019. Potential of $\mathrm{CO}_{2}$-EOR for NearTerm Decarbonization. Frontiers in Climate, 1: 5. DOI: 10.3389/ fclim.2019.00005.

Rahimi V., Bidarigh, M., Bahrami, P., 2017. Experimental Study and Performance Investigation of Miscible Water-Alternating- $\mathrm{CO}_{2}$ Flooding for Enhancing Oil Recovery in the Sarvak Formation. Oil \& Gas Sciences and Technology - Revue d'IFP Energies nouvelles, 72, 6: 1-12. DOI: 10.2516/ogst/2017030.

Skauge A., Aarra M.G., 1993. Effect of Wettability on the Oil Recovery by WAG. $7^{\text {th }}$ European Symposium on Improved Oil Recovery, 26-28 October 1993, Moscow, Russia.

Surguchev L.M., Korbel R., Haugen S., Krakstad O.S., 1992. Screening of WAG Injection Strategies for Heterogeneous Reservoirs. European Petroleum Conference, Cannes, France, 16-18 November. DOI: 10.2118/25075-MS.

U.S. Energy Information Administration, 2020. Short-Term Energy Outlook (STEO).

Wojnicki M., 2017a. Experimental investigations of oil displacement using the WAG method with carbon dioxide. Nafta-Gaz, 11: 864-870. DOI: 10.18668/NG.2017.11.06.

Wojnicki M., 2017b. Wspomaganie wydobycia ropy metodą naprzemiennego zatłaczania wody i gazu (WAG). Wiadomości Naftowe i Gazownicze, 8: 4-8.

Wojnicki M., 2019. Przykłady udanych wdrożeń metody naprzemiennego zatłaczania wody i gazu do węglanowych złóż ropy. Wiadomości Naftowe i Gazownicze, 22(1): 243.

Wojnicki M., 2020a. Naprzemienne zatłaczanie wody i gazu (WAG) wspomagane pianą (FAWAG) jako efektywna metoda EOR w złożach szczelinowatych i heterogenicznych. Nafta-Gaz, 5: 311-321. DOI: 10.18668/NG.2020.05.04.

Wojnicki M., 2020b. Ocena skuteczności naprzemiennego zatłaczania wody i gazu w procesie pozyskiwania ropy naftowej ze złóż węglanowych - studium eksperymentalne. Niepublikowana rozprawa doktorska, Politechnika Śląska, Gliwice.

Wojnicki M., Lubaś J., Warnecki M., Kuśnierczyk J., Szuflita S., 2020. Experimental studies of immiscible high-nitrogen natural gas WAG injection efficiency in mixed-wet carbonate reservoir. Energies, 13(9): 2346. DOI: 10.3390/en13092346.

Wojnicki M., Warnecki M., Kuśnierczyk J., Szuflita S., 2017. Ocena skuteczności wypierania ropy metodą WAG z wykorzystaniem gazów kwaśnych. Praca INiG - PIB, nr zlec. 1887/KB/2017, Archiwum Instytutu Nafty i Gazu - Państwowego Instytutu Badawczego, Kraków.

Wojnicki M., Warnecki M., Szuflita S., Kuśnierczyk J., Biały S., 2019. Laboratoryjne badania efektywności metody WAG (EOR) wspieranej chemicznie w węglanowych skałach zbiornikowych. Praca statutowa INiG - PIB, nr zlec. 0033/KB/2019, Archiwum Instytutu Nafty i Gazu - Państwowego Instytutu Badawczego, Kraków.

Zolfaghari H., Zebarjadi A., Shahrokhi O., Ghazanfari M.H., 2013. An Experimental Study of CO2-low Salinity Water Alternating Gas Injection in Sandstone Heavy Oil Reservoirs. Iranian Journal of Oil \& Gas Science and Technology, 2(3): 37-47. DOI: 10.22050/ IJOGST.2013.3643.

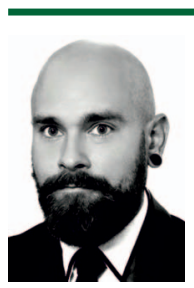

Mgr inż. Mirosław WOJNICKI

Asystent w Zakładzie Badania Złóż Ropy i Gazu

Instytut Nafty i Gazu - Państwowy Instytut Badawczy ul. Lubicz 25 A

31-503 Kraków

E-mail:miroslaw.wojnicki@inig.pl

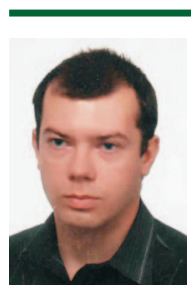

Mgr inż. Jerzy KUŚNIERCZYK

Specjalista badawczo-techniczny w Zakładzie

Badania Złóż Ropy i Gazu

Instytut Nafty i Gazu - Państwowy Instytut Badawczy ul. Lubicz $25 \mathrm{~A}$

31-503 Kraków

E-mail: jerzy.kusnierczyk@inig.pl

Mgr inż. Sławomir SZUFLITA
Asystent w Zakładzie Badania Złóż Ropy i Gazu
Instytut Nafty i Gazu - Państwowy Instytut Badawczy
ul. Lubicz 25 A
31-503 Kraków
E-mail: slawomir.szuflita@inig.pl

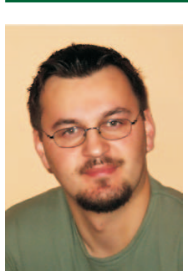

Dr inż. Marcin WARNECKI

Kierownik Zakładu Badania Złóż Ropy i Gazu

Instytut Nafty i Gazu - Państwowy Instytut Badawczy ul. Lubicz $25 \mathrm{~A}$

31-503 Kraków

E-mail: marcin.warnecki@inig.pl 